\title{
Nexus between Economic Growth, Investment, and Islamic Banking Development: The Case of Dual Banking System
}

\author{
Nosheen ${ }^{1 *}$, Abdul Rashid ${ }^{2}$ \\ ${ }^{1}$ National University of Modern Languages, Islamabad, Pakistan \\ ${ }^{2}$ International Islamic University, Islamabad, Pakistan
}

\section{Keywords}

Financial Development

Islamic Banking Development

Conventional Banking Development

Economic Growth

System GMM

Received: 29 September 2020

Accepted: 02 December 2020

\begin{abstract}
This research aims to study the impact that banking development attributed to Islamic banks is instigating on the economic growth and domestic investment in a dataset consisting of 20 countries having Islamic and conventional banks operating side by side over the period 1995 to 2014, using the "two-step system GMM" technique. Furthermore, it also inspects the difference in the impact that Islamic banking development is asserting on economic activity as compared to the impact attributed to conventional banking development using four measures of banking sector development namely, depth of financial intermediation, size of financial intermediation, credit to the private sector, and the ratio of assets of banks to the total banking assets. Our findings suggest that Islamic banks promote economic growth and domestic investment by increasing the depth and size of their intermediation, and by extending more credit to the private sector. Conventional banking development also stimulates economic growth and domestic investment by increasing its assets as a percentage of total banking assets. Islamic banking has a more meaningful impact on economic activity as its transactions are based on physical assets and linked to the real economy. Sharī'ah promotes social justice and equity and prohibits them from undertaking harmful products and activities.
\end{abstract}

KAUJIE Classification: I2, L25

JEL Classification: O1, O40, G21, Z12

(c) 2020 JIBM. All rights reserved.

\section{INTRODUCTION}

The purpose of the establishment of Islamic Banking is to create welfare in society apart from earning a profit (Abduh \& Chowdhury, 2012). Islamic banks play their part by ensuring access to financial services according to the Shari ${ }^{-}$ah principles. Considering the inherent destructions of interest-based system, removing the interest element from the system should be benefiting the whole economy in addition to the bank-based benefits of removing interest.

\footnotetext{
${ }^{*}$ Corresponding author: Nosheen

†Email: dr.nosheen@numl.edu.pk
} 
Islamic banks can safeguard the economy from the evil effects of interest (Furqani \& Mulyany, 2012). According to Karich (2002), "one of the prime reasons behind the establishment of the interest-free banking system is to improve the economic and social well-being of the people, and ensuring increased access of fair banking services to a majority of people". Islamic finance contributes to economic welfare by encouraging ethical and moral values (Boukhatem \& Moussa, 2018; Imam \& Kpodar, 2013; Kassim, 2016). Imam and Kpodar (2016) are of the view that "Islamic banking can stimulate growth because it acts as a shock absorber for countries subject to large shocks and enhances financial stability as Islamic banks are less prone to the crisis".

This paper examines the impact of banking sector development on economic growth and domestic investment in a set of countries having a dual banking system (DBS) in which both Islamic banks (IB) and conventional banks (CB) operate simultaneously. Furthermore, we also compare the differential impact of Islamic and conventional banking development on economic activity using data of $62 \mathrm{IB}$ and $280 \mathrm{CB}$ operating in 20 countries during the period 1994 to 2014 using four different measures of banking sector development. Islamic banking development is indicated by; depth of Islamic intermediation, size of Islamic intermediation, credit extended by IB to the private sector, and the ratio of assets of IB to the total banking assets. Similarly, conventional banking development is indicated by the depth of their intermediation, size of conventional intermediation, credit extended by $\mathrm{CB}$ to the private sector, and the ratio of assets of $\mathrm{CB}$ to the total banking assets. The analysis used dynamic growth and investment models including the lagged variable of growth and investment, banking sector development proxies, and macroeconomic determinants of growth and investment respectively.

The basic premise of this study is to witness the role of Islamic banking development in an economy as non-interest based banking is now getting more developed in terms of customers, investments, and instruments. Linking banking sector development with economic growth and investment is an important issue to be addressed as an efficient banking system is essential for channeling the surplus funds from savers to the profitable investment avenues, which ultimately increases funds available for investment and helps in reducing constraints faced by investors. This ease in the channeling of funds and required liquidity reduces the cost and the risk associated with investment leading to an increase in capital accumulation (Muyambiri \& Odhiambo, 2017). Capital accumulation further leads to economic growth due to the efficient allocation of funds, formulation of physical and human capital, and advancement in technology (Beck \& Levine, 2004; Creane et al., 2004; Ndikumana, 2005). Levine (2005) states that "financial development is defined as involving improvements in producing information about possible investments and allocating capital; monitoring firms and exerting corporate governance; facilitation of trading, diversification, and management of risk; mobilization and pooling of savings; and easing the exchange of goods and services".

Islamic banking development, due to its Sharī'ah-based principles, may stimulate economic growth and domestic investment in an economy. Islamic banking discourages interest, gambling, uncertainty, speculation, and loan trading. All of these prohibitions encourage businesses linked to the real economy and promote productive activities. Islamic banking 
development ensures the access of financial services to the people in line with the Shari' $a$ ah principles. The restrictions imposed by Shari'‘ ah in terms of prohibition of interest, uncertainty, etc. help in creating a stable financial system capable of increasing investment and sustainable economic growth. Islamic banking mobilizes savings, promotes investment and financing activities, encourages ethical financial ventures, and contributes to overall financial stability (Imam \& Kpodar, 2016).

The tendency of financial sector development (FD) to stimulate economic activity was first recognized by Bagehot (1873). He stated that the financial system, by easing the mobilization of capital, encouraged industrialization in England. There are three schools of thoughts that assume three different perspectives to this relationship. First, the supply-leading hypothesis states that financial development promotes economic growth and is considered to be a necessary requirement to achieve economic growth (Goldsmith, 1955; Patrick, 1966; Schumpeter \& Backhaus, 1911). The impact is through the channel of capital formation (Goldsmith, 1955; Quartey \& Prah, 2008). Second, the demand-following hypothesis considers financial development to be the byproduct of economic growth. When there is economic prosperity people demand more financial services due to which financial institutions evolve (Robinson, 1952; Stern, 1989). The third hypothesis states a bi-directional relationship where both are considered to be complementing each other (Jung, 1986; Lewis Jr, 1955; Luintel \& Khan, 1999).

The Accelerator Investment Theory suggests that financial development influences domestic investment using real output growth (Jorgenson, 1971). According to Ndikumana (2000) "financial development has an accelerator-enhancing impact on domestic investment i.e. the overall level of financial development makes domestic investment more responsive to output growth." Financial development induces the flow of financial resources to investors to meet the growing demand for output. An increase in GDP growth induces firms to increase their investment, which increases the profit margins. The fixed investment and the capital stock of firms go up leading to capital accumulation and hence the domestic investment.

Abduh and Chowdhury (2012), Abduh and Omar (2012), Furqani and Mulyany (2012) and Tabash and Dhankar (2014) are the limited studies analyzing the impact of Islamic banking development. The literature on Islamic banking development is mainly focused on examining the impact of Islamic financing/deposits on economic growth and no study to date is conducted that observes the effect of Islamic banking development on domestic investment. The contribution of our analysis is twofold. Firstly, this study analyses this relationship in 20 countries having DBS however; previous studies conducted within the Islamic framework examined this link in a single country. Second, we examined the contribution of Islamic banking developments individually by using the four traditional measures of financial development. This study is different from the previous studies with respect to the measurement of banking sector development attributed to IB and CB. This analysis fills the gap in the literature by measuring the extent to which abandoning interest-based transactions led IB to promote economic activity.

The remaining paper consists of the following sections. Section 2 describes the previous literature. Section 3 presents data and variables construction. Section 4 explains the econo- 
metric framework. Section 5 examines the empirical findings and finally, Section 6 provides the conclusion.

\section{LITERATURE REVIEW}

Previous literature reveals that the connection between economic growth, domestic investment, and banking sector development has been studied extensively. However, Islamic banking development is an emerging issue, which requires a thorough investigation. The large strand of the previous literature is focused on examining the correlation between FD and growth. The majority of this literature established a positive relationship (Adna Hye, 2011; Agbetsiafia, 2004; Atindehou et al., 2005; Beck \& Levine, 2004; Campos et al., 2012; Ciftci et al., 2017; Herwatz \& Walle, 2014; Jalil \& Ma, 2008; Levine \& Zervos, 1998; Pradhan, 2014; Pradhan et al., 2017; Zhang et al., 2012). In contrast, Hye and Islam (2013) and Narayan and Narayan (2013) found a negative relationship.

The literature investigating the causal relationship reported three types of relationships. The literature on supply leading hypothesis includes the following studies; Adu et al. (2013), Ahmed and Ansari (1998), Bittencourt (2012), Christopoulos and Tsionas (2004), Goldsmith (1955), Hasan et al. (2009), King and Levine (1993), Mahmood (2014), Mehrara et al. (2012), Rousseau (1998), Spears (1992) and Uddin and Shahbaz (2013). Along the same lines, Inoubli and Khallaouli (2011) found that only when the economy achieves a specific level of FD, the role of the FD becomes prominent. The contribution of FD is weak below this level and above which the contribution is strong. Researchers, such as McKinnon (1973) and Shaw (1973) are of the view that the "capital formulation is dependent on the rate of return on real cash balances". When the real interest rate is low or negative, savings are curtailed due to which funds available for investment decreases and hence the economic growth. McKinnon-Shaw model postulated that the contributing role of financial development in the economy is constrained by the government interventions on the financial sector, which includes high reserve requirements, control over the interest rate, and administrative allocation of bank credits.

The demand-following relationship is also established by numerous studies such as, Adamopoulous (2010), Chandavarkar (1992), Kuznets (1955), Liang and Tang (2006), Lucas (1988), Robinson (1952). Studies that established bi-directional relationship includes; Bader and Qarn (2008), Demetriades and Hussein (1996), Luintel and Khan (1999) and Rufael (2009).

The literature on domestic investment includes; Benhabib and Spiegel (2000), Fowowe (2011), Matsheka (1998), Muyambiri and Odhiambo (2017), Ndikumana (2000), Ndikumana (2005), Odedokun (1996), and Ucan and Ozturk (2011), all of which found a positive impact of banking development on domestic investment. Furthermore, Nasir and Khalid (2004) found a positive impact of interest rates and domestic savings on investment. Similarly, Salahuddin et al. (2009) found a positive impact of per capita real GDP and trade openness on investment. Dutta and Roy (2009) found that the need to have a well-established financial system depends upon the existing investment climate in a country. Mushtaq and Siddiqui (2016) suggested that interest rate and inflation have negative, while trade flows have positive 
impact on investment. Furthermore, credit extended to the private sector has an inverse relation with investment in non-Islamic countries.

Limited studies on Islamic banking development includes; Abduh and Omar (2012), Abduh and Chowdhury (2012), Boukhatem and Moussa (2018), Farahani and Dastan (2013), Furqani and Mulyany (2012), Kassim (2016), Manap et al. (2012), Tabash and Anagreh (2017) and Yusof and Bahlous (2013) which established a positive impact. Boukhatem and Moussa (2018) further stated that the institutional framework of IB should be well developed for this impact to be more significant. Furthermore, Tabah and Dhankar (2014) found a bi-directional relationship. Along the same lines, Abedifar et al. (2016) found that the presence of IB promotes economic welfare. Imam and Kapodar (2016) suggested that Islamic banking promotes the growth of the economy despite its small size. Smaoui and Nechi (2017) found that the development of Sukuk markets also induces long-run economic growth.

Prior literature has provided rich evidence regarding the contribution of banking sector development in inducing economic activity. However, these studies have also left a gap in our knowledge regarding the significance of Islamic banking development. Notably, our understanding of the behavior of Islamic banking development regarding their contribution to economic activity is relatively incomplete. Being limited in number, the literature on Islamic banking development is largely focused on economic growth. Domestic investment, however, is the area that remained under-researched. In this study, we bridge the gap in Islamic banking literature that how far IB are successful in inducing growth and investments in the economy. We expect that IB, due to their inherent features, is in a better position to induce economic prosperity. This area should be widely investigated to reap the long-run benefits of non-interest-based banking. Analysis of the existing literature reveals that all of these studies used just the crude measures of Islamic banking development. Our study is distinct with respect to the measurement of banking sector development attributed to IB and CB separately.

\section{DATA AND VARIABLE CONSTRUCTION}

\section{Data and Sample Sources}

The study uses annual data of 20 countries having a dual banking system. Data of 62 IB and $218 \mathrm{CB}$ has been taken to develop the financial development indicators separately for Islamic and conventional banks over the period 1995-2014. We used Datastream and Bankscope database to get bank-level data, and data on country-level variables are taken from World Bank, IMF, and Federal Reserve Economic database.

\section{Variables Construction}

In this section construction of dependent and independent variables is discussed.

\section{Dependent Variable}

Dependent variables used are economic growth (GDP) indicated by the "growth rate of real GDP". Second domestic investment (GCF) is defined as "the gross capital formation as a percentage of GDP". 


\section{Independent Variables}

Independent variables include banking development indicators and macroeconomic variables the choice of which is strictly in conformity with the previous literature. The measures used to represent each variable are explained as follows;

\section{Financial Development}

Financial development has been measured using four different indicators of banking sector development attributed to IB and CB individually. First, the depth of financial intermediation (DOI) is given by "the ratio of total loans in the financial system to GDP" (Zhang et al., 2012). Depth of Islamic intermediation is given by total loans of IB as a percentage of GDP, and depth of conventional intermediation is measured by dividing total loans of CB by GDP. Second, the size of financial intermediation (SOI) is given by "the ratio of total deposits in the financial system to GDP" (Zhang et al., 2012). Size of Islamic intermediation is indicated by total deposits of IBs as percentage of GDP. Similarly, size of conventional intermediation is given by dividing total deposits of CBs to GDP. The third measure (CPS) is the "ratio of credit to private sector by deposit-money bank to GDP" (Federici \& Caprioli, 2009). It measures the domestic asset distribution. For Islamic banks it is measured by domestic credit to private sector by IBs to GDP and for conventional banks it is given by dividing the domestic credit to the private sector by CBs by GDP. The fourth measure (ATA) is the "ratio of assets of the bank divided by the total assets of the central banks, Islamic banks and conventional banks" (Federici \& Caprioli, 2009). For IBs it is measured by the ratio of assets of IBs to the total banking assets. Similarly, for CBs it is indicated by the ratio of assets of CBs to total banking assets.

\section{Controlled Variables}

\section{Determinants of Economic Growth}

The macroeconomic determinants of economic growth used are; first inflation (INF) is defined as "the year-on-year percentage change of the CPI index". Theoretically, there are two schools of thoughts governing the link between inflation and growth. One school of thought known as Mundell-Tobin effect considered money and capital substitutes. It states that when the level of inflation rises, the interest rate reduces which stimulates investment and economic growth. People substitute capital for money when the cost of holding money increases (Mundell, 1965; and Tobin, 1965). The conflicting view states that inflation impacts economic growth negatively. Inflation increases the effective cost of investment, the inefficiency of the price mechanism, and uncertainty in the macroeconomic environment (Fischer, 1981).

Second, trade openness (T.OPEN) is given by "the sum of exports and imports as the percentage of GDP". It impedes as well as promotes economic growth. Trade openness promotes economic growth by increasing the overall production in the economy through the expansion of imports of domestic goods and services (Grossman \& Helpman, 1991). Trade openness halts economic growth when it leads to a reduction in tariffs which hurts domestic manufacturing by reducing its price relative to foreign goods and making domestic goods less attractive (Batra, 1992; Batra \& Slottje, 1993). Third, GFCF is given by "gross fixed 
capital formation as a percentage of GDP". Capital stock has a positive relationship with economic growth. Previous literature provided evidence regarding the negative impact of inflation and the positive impact of openness and GFCF on economic growth (Inoubli \& Khallaouli, 2011; Narayan \& Narayan, 2013).

\section{Determinants of Domestic Investment}

The macroeconomic determinants of domestic investment include; GDP growth "measured by the growth rate of real GDP". According to the neoclassical theory of investment, GDP growth exerts a positive impact on domestic investment i.e. the increase in domestic investment to meet the aggregate demand for output. This relationship is governed by the accelerator effect and well established in the previous literature, which includes Fielding (1997), Greene and Villanueva (1991), Ndikumana (2000) and Wai and Wong (1982).

Second, real interest rate (RIR), "the lending interest rate adjusted for inflation". McKinnon (1973) and Shaw (1973) states that "higher interest rates on deposits attract more real balances, which results in more investment". Contrary to it, the neo-classical view suggests that the cost of capital increases due to higher interest rates which reduces investment. The neo-classical view states that the real interest rate influences domestic investment through the channel of domestic savings. Third, per capita GDP (P.C.GDP) (annual \%) is "gross domestic product divided by midyear population".

Fourth, we use domestic savings (D.SAV) (percentage of GDP). According to Ndikumana (2000), the traditional view states that domestic savings are the most important determinant of domestic investment. Domestic savings have a positive impact on domestic investment.

Fifth, we used Govt. consumption expenditure (GOV.CON) (percentage of GDP). Government consumption can influence domestic investment through the crowding of private investment. Govt. borrowings from the financial system to finance the budget deficit reduces the private investment. Sixth, inflation (INF), "the year-on-year percentage change of the CPI index". A high level of inflation reduces domestic investment. It discourages investors from undertaking long-term projects and also discourages banks to lend on long-term, which ultimately reduces investment. Seventh, trade-openness (T.OPEN), "the sum of exports and imports as the percentage of GDP". Levine and Renelt (1992) found that trade-openness has a positive impact on domestic investment when the increase in exports brings foreign exchange in the country which can be used to import capital goods used to produce more domestic goods. Similarly, imports of investment goods induce the domestic investment and the imports of consumer goods curtail the domestic production.

\section{Econometric Framework}

\section{Empirical Models}

The empirical model consists of an economic growth model and investment model whereby the impact of banking sector development on economic growth and domestic investment is investigated employing the framework proposed by Narayan and Narayan (2013) and Ndikumana (2000) respectively while controlling for macroeconomic variables. Each model consists of four indicators of banking sector development attributed to IBs and CBs.

The impact of banking sector development on economic growth is given by the following 
model;

$$
G D P_{j t}=\alpha+\beta_{0} G D P_{j t-1}+\beta_{1} \sum X_{j t}+\beta_{2} F D_{j t}^{\text {Islamic }}+\beta_{3} F D_{j t}^{\text {Conventional }}+C_{j}+Y_{t}+\epsilon_{j t}
$$

Where $G D P_{j t}$ stands for the GDP growth rate of country $j$ at time $t . \sum X_{j t}$ is the vector of the country-specific variables, which includes inflation, $G F C F$, and trade openness. $F D_{j t}^{I s l a m i c}$ $D_{j t}^{\text {conventional }}$ is the financial development attributed to IB and CB respectively in country $j$ at time t. $C_{j}$ is the country's fixed effects and $Y_{t}$ measures time fixed effects. Bank-level data of financial development has been taken by calculating banking development separately for IB and $\mathrm{CB}$. To ascertain the differential impact of banking sector development owing to IB and $\mathrm{CB}$ upon economic growth, a test of differential impact is also applied. In particular, we test if the impact of Islamic banking development $F D_{j t}^{\text {Islamic }}, G D P_{j t}$ is the same as the impact of conventional banking development $F D_{j t}^{\text {Conventional }}$ i.e. $\left(\beta_{2}=\beta_{3}\right)$.

Second, the following model shows the impact of banking sector development on Investment;

$$
G C F_{j t}=\alpha+\beta_{0} G C F_{j t-1}+\beta_{1} \sum X_{j t}+\beta_{2} F D_{j t}^{\text {Islamic }}+\beta_{3} F D_{j t}^{\text {Conventional }}+C_{j}+Y_{t}+\epsilon_{j t}
$$

$G C F_{j t}$ stands for the gross capital formation of country $\mathrm{j}$ at time $\mathrm{t}, . \sum X_{j t}$ is the vector of country-specific variables which include GDP growth, inflation, and trade openness, real interest rate, Govt. consumption, per capita GDP growth, and domestic savings. In order to ascertain the differential impact of Islamic and conventional banking development on domestic investment, we test if the impact of Islamic banking development $F D_{j t}^{\text {Islamic }}$ on $G C F_{j t}$ is the same as the impact of conventional banking development $F D_{j t}^{\text {Conventional }}$ i.e. $\left(\beta_{2}=\beta_{3}\right)$.

\section{Estimation Techniques}

To estimate the proposed models, we used "Two-Step Robust System GMM" estimation technique developed by Arellano and Bover (1995) and Blundell and Bond (1998). According to Bond et al. (2001), "System GMM estimation method uses lagged levels of variables as instruments for differenced equations and lags of the first-differences of variables for equations in level". It uses the first difference of each underlying variable to removes the time-invariant unobservable firm-specific fixed effects. Secondly, it uses appropriate lags of independent variables as instrumental variables to mitigate the problem of endogeneity in the regressors.

\section{EMPIRICAL FINDINGS}

\section{Validity of the Instruments}

To ensure that the system GMM process is correctly specified, tests of overidentifying restriction and second-order serial correlation are applied. J-statistic of Hansen (1982), the test of overidentifying restrictions, is "asymptotically distributed as chi-square with the degree 
of freedom equal to the number of overidentifying restrictions". The null hypothesis of $\mathbf{J}$ Hansen test is that the instruments are uncorrelated with the error terms in the estimated equation. In addition, Arellano and Bond (1991) AR(2) test is applied to check the presence of second-order serial correlation in the residuals for each underlying model. The null hypothesis is that there is no serial correlation in the residuals. Since the model is dynamic in nature, there is a possibility that the model might exhibit first-order serial correlation, but second-order serial correlation should not be present in the residuals. The estimates from the above diagnostic tests are reported in Panel B of each table presented in the results section.

\section{Descriptive Statistics}

Table 1 shows descriptive statistics for dependent, financial development, and controlled variables. Dependent variables GDP and GCF have mean scores of 0.288 and 22.98 respectively. When we examine country-specific variables we find the mean score of 7.311, 84.90, 22.04, 5.520, 15.98, 1.376, and 25.97 for inflation, trade openness, GFCF, RIR, Govt. consumption, Per capita GDP growth, and domestic savings respectively. For the financial development, we find considerable differences with the mean score of all the measures of financial development being higher for conventional banking development.

\section{Regression Results and Discussion}

\section{Economic Growth and Banking Sector Development}

Table 2 reports the results of the impact of banking development on economic growth as estimated by Model (1). In column 2, the impact of depth of the financial intermediation on economic growth is reported. Depth of Islamic intermediation asserts a significantly positive impact in line with the findings of Kassim (2016), and Imam and Kapodar (2016). On the contrary, the depth of conventional intermediation shows insignificant impact. The test of differential impact implies a significant difference between IB and CB in terms of the impact of their DOI on economic growth. Regarding the impact of country-specific variables, inflation and GFCF both emphasize a significant positive impact on economic growth. Column 3 shows that an increase; both in the size of Islamic and conventional intermediation leads to a decrease in economic growth and the difference is statistically significant. Furthermore, GFCF and trade openness also exert positive impact.

Column 4 shows that an increase in Islamic banking credit to the private sector promotes economic growth consistent with the findings of Imam and Kapodar (2016). On the other hand, the impact of conventional banking domestic credit is insignificant. Inflation and GFCF have a significant positive effect, while the impact of trade openness appears to be statistically insignificant. The results are consistent with the previous literature, which includes Beck and Levine (2004) and Levine et al. (2000). In column 5 we find that percentage of assets of both IB and CB have a positive impact on economic growth. But the impact is slightly higher in the case of Islamic banking development in line with the findings of Imam and Kapodar (2016). Further, inflation and GFCF have a statistically significant positive impact. However, the impact of trade openness is statistically insignificant. 
TABLE 1

Descriptive Statistics

\begin{tabular}{llllll}
\hline \hline Variables & Observations & Mean & S.D & Min. & Max. \\
\hline GDP & 396 & 0.288 & 0.359 & -2.277 & 2.509 \\
GCF & 391 & 22.98 & 8.089 & 4.562 & 61.47 \\
Inflation & 396 & 7.311 & 12.21 & -3.846 & 84.64 \\
Trade Openness & 387 & 84.9 & 36.51 & 26.33 & 191.8 \\
GFCF & 368 & 22.04 & 7.974 & 2.918 & 58.96 \\
RIR & 289 & 5.52 & 10.23 & -20.13 & 41.25 \\
Govt. Consumption & 378 & 15.98 & 6.795 & 2.332 & 33.01 \\
Per Capita GDP Growth & 385 & 1.376 & 4.757 & -14.79 & 17.5 \\
Domestic Savings & 378 & 25.97 & 22.25 & -32.09 & 74.34 \\
\hline & & Islamic Banks & & & \\
\hline DOI & 227 & 7.623 & 9.95 & 0.000194 & 43.25 \\
SOI & 232 & 9.714 & 11.59 & 0.000453 & 59.57 \\
CPS & 94 & 3.618 & 2.842 & 0.0291 & 12.08 \\
ATA & 233 & 17.68 & 16.52 & 0.0187 & 80.77 \\
\hline & & Conventional Banks & & & \\
\hline DOI & 346 & 41.68 & 60.69 & 0.0852 & 271.6 \\
SOI & 346 & 49.24 & 67.07 & 0.315 & 303.8 \\
CPS & 184 & 26 & 36.18 & 0.0006 & 164.6 \\
ATA & 342 & 72.01 & 22.12 & 3.304 & 99.99 \\
\hline \hline
\end{tabular}

Results show that Islamic banking development enhances economic growth in line with the findings of Abedifar et al. (2016), Boukhatem and Moussa (2018), Gheeraert (2014), Imam and Kapodar (2016), Kassim (2016) and Tabash and Dhankar, (2014). IB has the ability to influence economic growth by altering DOI, CPS, and ATA ratio. However, CB can stimulate economic growth only by adjusting the ATA ratio. Moreover, results showed that banking sector development hinders economic growth when there is an increase in the size of both Islamic and conventional intermediation, and increase in credit extended to the private sector by CB in accordance with the findings of Adnan Hye and Islam (2013), and Narayan and Narayan (2013). This inverse relationship can be explained by McKinnon-Shaw model, which states that the government restrictions on the banking sector constraints its performance and negatively impacts economic growth. Furthermore, the inefficient allocation of capital also impedes economic growth (Zhang et al., 2012). Creane et al. (2004) found that this negative association is more evident in public sector banks, which are more influenced by government interventions.

These findings further suggest that IBs are in a better position to boost economic growth as compared to CBs. Islamic banking Sharí 'ah-based principles stimulate economic growth due to the unique nature of their activities which are linked to the real economy and are based on physical transactions. Moreover, Sharī'ah promotes social justice and equity, and 
prohibits IBs from undertaking harmful products and activities. According to Leon and Waille (2018), IBs promote economic growth by increasing the size of their intermediation. Islamic banking enhances macroeconomic efficiency, which contributes towards economic growth in the overall economy (Gheeraert \& Weill, 2015).

Islamic banks are not permitted to indulge in interest-based transactions in any form. Risk and risk-sharing arrangements enable them to share profit and loss with the depositors and the borrowers. IB with the profit-sharing mechanism are well equipped to sustain external shocks. Islamic banking development helps to minimize uncertainty in the financial system as it is prohibited by Sharí' ah to invest in speculative activities. IBs are more risk-averse than CBs as they attempt to choose low-risk projects. Similarly, the requirement of having a large portion of their deposits with central banks in order to meet the current depositors' needs also minimizes the chances of bank runs (Furqani \& Mulyany, 2012).

The establishment of Islamic banking influences financial sector development through many channels. First, IBs create opportunities for the individuals who want to invest their funds according to Shari' ${ }^{\circ}$ ah principles and undertake to share the risks and returns accordingly. This results in increased access of banking facilities to the group of people who previously were not able to access Islamic banking services. Second, IBs then strive to introduce financial modes to satisfy the needs of the investors willing for interest fee returns. It includes bringing financial innovation and product development, which may encourage CBs to offer products in order to compete with the Islamic financial products. Thirdly, the establishment of IBs or opening of Islamic branches or windows by CBs results in more competition and higher incentives for IBs to develop more specialized products (Gheeraert, 2014; Kalim et al., 2016).

\section{Investment and Banking Sector Development}

Table 3 reports the relationship between financial development and domestic investment as shown by Model (2). Column 2 displays that an increase in depth of Islamic intermediation is having a positive and depth of conventional intermediation has a significantly negative impact on domestic investment and the difference is statistically significant. With regards to the impact of country-specific variables, trade-openness is having a positive impact on domestic investment in line with the results of Ndikumana (2000), and Salahuddin et al. (2009). According to Ndikumana (2000), trade openness influences domestic investment through two channels. First, the increase in trade openness caused by imports of capital goods facilitates investment. Secondly, the increase in trade openness due to an increase in exports results in increased foreign exchange, which is used to buy investment goods from abroad. The increase in exports can also be a means to extend the market for local goods. Both these channels ultimately increase domestic investment.

Column 3 shows that the size of Islamic intermediation has significantly positive and the size of conventional intermediation has a negative impact and the differential impact is statistically insignificant. In addition, the positive impact of GDP growth shows the tendency of financial development to stimulate domestic investment through an increase in output growth. This evidence of accelerator enhancing effect is consistent with the previous literature that includes Dutta and Roy (2009), Ndikumana (2000) and Ndikumana (2005). 
TABLE 2

Economic Growth and Financial Development

\begin{tabular}{|c|c|c|c|c|}
\hline & Model 1 & Model 2 & Model 3 & Model 4 \\
\hline REGRESSORS & DOI & SOI & CPS & ATA \\
\hline \multicolumn{5}{|c|}{ Panel A: Estimation Results } \\
\hline$G D P_{(j t-1)}$ & $\begin{array}{l}0.0919 * * * \\
(0.0240)\end{array}$ & $\begin{array}{l}0.554 * * * \\
(0.0482)\end{array}$ & $\begin{array}{l}0.222 \\
(0.224)\end{array}$ & $\begin{array}{l}0.0451 * * * \\
(0.0142)\end{array}$ \\
\hline$I N F_{j t}$ & $\begin{array}{l}0.00588 * * * \\
(0.000245)\end{array}$ & $\begin{array}{l}-0.00139 \\
(0.00169)\end{array}$ & $\begin{array}{l}0.0832 * * * \\
(0.0146)\end{array}$ & $\begin{array}{l}0.0126^{* * * *} \\
(0.00105)\end{array}$ \\
\hline T.OPEN $N_{j t}$ & $\begin{array}{l}-0.000888 \\
(0.000695)\end{array}$ & $\begin{array}{l}0.000595^{*} \\
(0.000312)\end{array}$ & $\begin{array}{l}-0.00275 \\
(0.00251)\end{array}$ & $\begin{array}{l}-0.000022 \\
(0.000460)\end{array}$ \\
\hline$G F C F_{j t}$ & $\begin{array}{l}0.00853 * * * \\
(0.000994)\end{array}$ & $\begin{array}{l}0.00396 * * \\
(0.00156)\end{array}$ & $\begin{array}{l}0.0413 * * * \\
(0.0124)\end{array}$ & $\begin{array}{l}0.00969 * * * \\
(0.00286)\end{array}$ \\
\hline$D O I_{j t}^{\text {Islamic }}$ & $\begin{array}{l}0.00432 * \\
(0.00224)\end{array}$ & & & \\
\hline$D O I_{j t}^{\text {Conventional }}$ & $\begin{array}{l}-0.00117 \\
(0.000750)\end{array}$ & & & \\
\hline SOI $I_{j t}^{\text {Islamic }}$ & & $\begin{array}{l}-0.00141 * * * \\
(0.000327)\end{array}$ & & \\
\hline$S O I_{j t}^{\text {Conventional }}$ & & $\begin{array}{l}-0.000396 * * * \\
(8.08 \mathrm{e}-05)\end{array}$ & & \\
\hline$C P S_{j t}^{I s l a m i c}$ & & & $\begin{array}{l}0.0572 * * \\
(0.0186)\end{array}$ & \\
\hline$C P S_{j t}^{\text {Conventional }}$ & & & $\begin{array}{l}-0.00130 \\
(0.00189)\end{array}$ & \\
\hline$A T A_{j t}^{\text {Islamic }}$ & & & & $\begin{array}{l}0.00521 * * * \\
(0.000941)\end{array}$ \\
\hline$A T A_{j t}^{\text {Conventional }}$ & & & & $\begin{array}{l}0.00407 * * * \\
(0.000631)\end{array}$ \\
\hline Constant & $\begin{array}{l}0.163 * * * \\
(0.0464)\end{array}$ & $\begin{array}{l}0.0107 \\
(0.0289)\end{array}$ & $\begin{array}{l}-1.005 \\
(0.640)\end{array}$ & $\begin{array}{l}-0.400 * * * \\
(0.0637)\end{array}$ \\
\hline
\end{tabular}

Panel B: Tests for differential effects of Variables

\begin{tabular}{ll}
$\beta_{\text {DOI }}^{\text {Islamic }} \beta_{\text {DOI }}^{\text {Conventional }}$ & 3.79 \\
$p$-value & 0.0673 \\
$\beta_{\text {SOI }}^{\text {Islamic }} \beta_{\text {SOI }}^{\text {Conventional }}$ & 9.69 \\
$p$-value & 0.0060 \\
$\beta_{C P S}^{\text {Islamic }} \beta_{C P S}^{\text {Conventional }}$ & 8.49 \\
$p$-value & 0.0172 \\
$\beta_{\text {ATA }}^{\text {Islamic }} \beta_{\text {ATA }}^{\text {Conventional }}$ & 1.50 \\
$p$-value & 0.2362 \\
\hline
\end{tabular}

Panel C: Diagnostic Tests

\begin{tabular}{lllll} 
Observations & 203 & 208 & 76 & 208 \\
Countries & 19 & 19 & 10 & 19 \\
AR(2) & 1.24 & 1.59 & -0.28 & 1.01 \\
$p$-value & 0.214 & 0.111 & 0.782 & 0.314 \\
$J$-statistic & 15.18 & 14.17 & 3.75 & 11.90 \\
$p$-value & 0.999 & 0.997 & 0.710 & 0.987 \\
\hline \hline
\end{tabular}

Standard errors in parentheses, $* * * p<0.01, * * p<0.05, * p<0.1$ 
TABLE 3

Investment and Financial Development

\begin{tabular}{|c|c|c|c|c|}
\hline & Model 1 & Model 2 & Model 3 & Model 4 \\
\hline REGRESSORS & DOI & SOI & CPS & ATA \\
\hline \multicolumn{5}{|c|}{ Panel A: Estimation Results } \\
\hline$G C F_{j t-1}$ & $\begin{array}{l}0.187 \\
(0.360)\end{array}$ & $\begin{array}{l}0.838 * * * \\
(0.193)\end{array}$ & $\begin{array}{l}0.571 \\
(0.490)\end{array}$ & $\begin{array}{l}0.462 \\
(0.311)\end{array}$ \\
\hline$G D P_{j t}$ & $\begin{array}{l}13.98 \\
(14.60)\end{array}$ & $\begin{array}{l}10.52 * * \\
(3.770)\end{array}$ & $\begin{array}{l}-84.65 \\
(55.26)\end{array}$ & $\begin{array}{l}-6.918 \\
(21.46)\end{array}$ \\
\hline$I N F_{j t}$ & $\begin{array}{l}0.232 \\
(0.391)\end{array}$ & $\begin{array}{l}-0.485 * * * \\
(0.155)\end{array}$ & $\begin{array}{l}0.823 \\
(0.766)\end{array}$ & $\begin{array}{l}0.413 * * * \\
(0.0565)\end{array}$ \\
\hline$T . O P E N_{j t}$ & $\begin{array}{l}0.424 * * \\
(0.148)\end{array}$ & $\begin{array}{l}0.103 \\
(0.0618)\end{array}$ & $\begin{array}{l}1.034^{*} \\
(0.546)\end{array}$ & $\begin{array}{l}-0.0535 \\
(0.113)\end{array}$ \\
\hline$R I R_{j t}$ & $\begin{array}{l}0.00242 \\
(0.161)\end{array}$ & $\begin{array}{l}-0.000348 \\
(0.0554)\end{array}$ & & $\begin{array}{l}-0.158 * * * \\
(0.0217)\end{array}$ \\
\hline$G O V . C O N_{j t}$ & $\begin{array}{l}0.425 \\
(0.714)\end{array}$ & $\begin{array}{l}-0.566 * * * \\
(0.164)\end{array}$ & $\begin{array}{l}7.270^{*} \\
(3.762)\end{array}$ & $\begin{array}{l}1.625 * * * \\
(0.465)\end{array}$ \\
\hline$P C . G D P_{j t}$ & $\begin{array}{l}-0.420 \\
(0.906)\end{array}$ & $\begin{array}{l}0.263 \\
(0.515)\end{array}$ & $\begin{array}{l}3.885 \\
(2.839)\end{array}$ & $\begin{array}{l}-0.555 \\
(1.030)\end{array}$ \\
\hline D.SAV $V_{j t}$ & $\begin{array}{l}-0.259^{* *} \\
(0.110)\end{array}$ & $\begin{array}{l}-0.305 \\
(0.213)\end{array}$ & $\begin{array}{l}-1.162 \\
(0.664)\end{array}$ & $\begin{array}{l}0.0713 \\
(0.121)\end{array}$ \\
\hline$D O I_{j t}^{\text {Islamic }}$ & $\begin{array}{l}0.819^{*} \\
(0.427)\end{array}$ & & & \\
\hline$D O I_{j t}^{\text {Conventional }}$ & $\begin{array}{l}-0.231 * * \\
(0.0853)\end{array}$ & & & \\
\hline$S O I_{j t}^{\text {Islamic }}$ & & $\begin{array}{l}0.303 * * \\
(0.122)\end{array}$ & & \\
\hline SOI $I_{\text {jt }}^{\text {Conventional }}$ & & $\begin{array}{l}-0.0368 * * \\
-0.0368 * *\end{array}$ & & \\
\hline$C P S_{j t}^{\text {Islamic }}$ & & & $\begin{array}{l}2.917^{*} \\
((1.553))\end{array}$ & \\
\hline$C P S_{j t}^{\text {Conventional }}$ & & & $\begin{array}{l}-0.899 * \\
((0.457))\end{array}$ & \\
\hline$A T A_{j t}^{\text {Islamic }}$ & & & & $\begin{array}{l}0.00521 \text { *** } \\
(0.0663)\end{array}$ \\
\hline$A T A_{j t}^{\text {Conventional }}$ & & & & $\begin{array}{l}0.339^{* *} \\
(0.133)\end{array}$ \\
\hline Constant & $\begin{array}{l}-16.08 \\
(22.10)\end{array}$ & $\begin{array}{l}10.88 \\
(8.448)\end{array}$ & $\begin{array}{l}-105.6 \\
(63.46)\end{array}$ & $\begin{array}{l}-34.83 * * \\
(15.39)\end{array}$ \\
\hline
\end{tabular}

Panel B: Tests for differential effects of Variables

$\beta_{D O I}^{\text {Islamic }} \beta_{D O I}^{\text {Conventional }} 4.93$

Panel B: Tests for differential effects of Variables

\begin{tabular}{|c|c|c|c|c|}
\hline & & & & \\
\hline$\beta_{D O I}^{\text {Islamic }} \beta_{D O I}^{\text {Conventional }}$ & 4.93 & & & \\
\hline$p$-value & 0.0413 & & & \\
\hline$\beta_{\text {SOI }}^{\text {Islamic }} \beta_{\text {SOI }}^{\text {Conventional }}$ & 6.81 & & & \\
\hline$p$-value & 0.0197 & & & \\
\hline$\beta_{C P S}^{\text {Islamic }} \beta_{C P S}^{\text {Conventional }}$ & 3.61 & & & \\
\hline$p$-value & 0.0899 & & & \\
\hline$\beta_{A T A}^{\text {Islamic }} \beta_{A T A}^{\text {Conventional }}$ & 13.57 & & & \\
\hline$p$-value & 0.0020 & & & \\
\hline \multicolumn{5}{|c|}{ Panel C: Diagnostic Tests } \\
\hline Observations & 155 & 142 & 80 & 159 \\
\hline Countries & 17 & 16 & 10 & 17 \\
\hline $\mathrm{AR}(2)$ & -0.43 & -0.91 & -1.100 & .15 \\
\hline$p$-value & 0.664 & 0.365 & 0.273 & 0.879 \\
\hline$J$-statistic & 12.04 & 7.28 & 0.00 & 6.49 \\
\hline$p$-value & 0.991 & 0.996 & 1.000 & 0.994 \\
\hline
\end{tabular}


Furthermore, inflation and Govt. consumption both are negatively related to domestic investment. The negative impact of inflation is in line with the findings of Fowowe (2011), Ndikumana (2000) and Ucan and Ozturk (2011). The negative relationship between Govt. consumption is governed by the crowding-out effect. Public borrowing by Govt. for consumption expenditure ultimately decreases the funds available for investment.

Column 4 shows that increase in the credit extended provided by IB leads to increase in domestic investment in line with the findings of Matsheka (1998), and Muyambiri and Odhiambo (2017). In contrast, the impact of domestic credit by the conventional banking sector is negative. The results of country-specific variables show that there is a positive impact of trade openness in line with the results of Ndikumana (2000), and Salahuddin et al. (2009). In column 5, the impact of assets of IB is statistically insignificant and the impact of assets of $\mathrm{CB}$ on investment is positive in line with the findings of Benhabib and Spiegel (2000). Regarding country-specific variables, the real interest rate asserts a negative impact on domestic investment supporting the findings of Bader and Malawi (2010), Muhammad et al. (2013) and Ucan and Ozturk (2011).

Results support the hypothesis that improvement in banking sector development stimulates domestic investment, which is more evident in the case of Islamic banking development. Alternatively, conventional banking development stimulates economic growth when ATA is used. Conventional banking development impedes domestic investment in case of depth and size of financial intermediation, whereas no evidence that Islamic banking development retards domestic investment has been found.

Islamic banking development plays a vital role in increasing economic activity. IBs pool surplus funds of the savers in the form of risk and return sharing. With this mechanism of risk and return sharing, the spirit of Sharī'ah principles is maintained and the practice of paying fixed return is discouraged, as it is a liability on the bank and a burden on the economy. Risk and return sharing encourages depositors to fully participate in their investment. The cost of collecting savings is also minimized as they serve the purpose of fulfilling the financial needs of the people desirous of Sharī ah-based returns who themselves approach IBs for this need. Secondly, Islamic banks financing is entirely in the real sector in the form of modes such as; murābahah, salam, ijärah, istișna $\bar{a}^{6}$. IBs do not lend money on interest but they finance the venture instead. IBs are bound to allocate financial resources in the real economy accompanied by physical transactions and tangible assets. For instance, murābahah is a contract of sale in which IBs purchase a commodity on behalf of the client and sell this product to the client at a cost, which includes the price plus an agreed profit margin for the bank. Murābahah is used to finance consumers as well as real sectors of the economy. It is a source of financing in consumer finance for the purchase of consumers durable goods e.g. cars etc., in the real estate sector to finance the housing, etc., in the production and agriculture sector to finance the purchase of machinery, equipment etc.

Salam is a forward contract wherein the buyer pays the price of the subject matter in advance and the delivery is deferred to a specified time in the future. Salam is usually used to meet the needs of the small farmers who need money to grow their crops and the needs of the traders for imports and exports. Similarly, istisnna ${ }^{`}$ is a type of sale contract in which the buyer 
places an order with the seller to manufacture certain assets. It is a contract of manufacturing used by IBs to finance different kinds of projects such as the construction of buildings, houses, plants, roads, machines, equipment, and the manufacturing of aircrafts, etc. The majority of the Islamic modes of finance are linked to the agriculture sector and the industrial sector, which contributes to domestic investment and hence the economic growth. Third, financing of the private sector brings the private sector in inducing prosperity in the economy. Islamic banking development ensures the efficient allocation of resources and investment among different sectors of the economy. IBs offer customized financial products that are designed considering the requirements of specific sectors of the economy. IBs through microfinancing are becoming a substantial source of finance for investors with little or no access to financial markets.

\section{Conclusions}

This analysis examines the impact of Islamic banking development on economic growth and domestic investment for a panel of 20 countries operating in a DBS. We also examine the differential impact of Islamic and conventional banking development on economic growth and domestic investment using four measures of banking development attributed to IBs and CBs individually namely, depth of financial intermediation, size of financial intermediation, credit to the private sector, and the ratio of assets of banks to the total banking assets.

This analysis finds that the Islamic financial system is efficient enough to induce growth and domestic investment in the economy. Results suggest that Islamic banking stimulates enhances economic growth by increasing the depth of their intermediation, domestic credit to the private sector, and by increasing their assets as a percentage of total banking assets. Islamic banking contributes towards inducing domestic investment by increasing the depth and size of their intermediation, and by extending more credit to the private sector. Conventional banking development induces economic growth and domestic investment by increasing their assets as compared to the total banking assets. The impact is more meaningful in the case of Islamic banking development. Islamic banking stimulates economic activity due to the unique nature of its activities, which are linked to the real economy and are based on physical transactions. Moreover, Sharī'ah promotes social justice and equity, and prohibits Islamic banks from undertaking harmful products and activities. Risk and return sharing forms the basis of the contribution of IB in the real economy which helps in better utilization of financial resources, enhances productivity by allocating resources to productive ventures, which promotes investment and leads to sustainable economic growth.

The evidence implies that countries with dual banking system can gain from the resilience provided by the Islamic banks in terms of promoting assets based activities thereby protecting the whole financial system. The government should take steps in order to promote an interest-free banking system considering its inherent benefits. Setting the desired target of Islamic banking assets as compared to total banking assets, improvement of Islamic financial infrastructure and Islamic banking regulations further induces economic activity. In order to increase the efficiency of the banking system; the macroeconomic environment and legal environment should be well developed. In addition, caution should be exercised in the choice 
of banking sector proxy while formulating growth-enhancing policies.

There are a number of issues that remained unaddressed in this study that paves the way for future research. First, the same research can be conducted by expanding the time frame and the number of countries. Secondly, the lack of data with respect to the calculation of banking sector development attributed to Islamic and conventional banks was a very big limitation of this study e.g. aggregate data on credit to the private sector by the whole economy is easily accessible but the data of credit to the private sector by an individual bank is not reported by all banks in their accounts. Thirdly, this analysis is conducted considering the linear relationship between financial development and economic activity, but the relationship is non-linear in nature. The same analysis can be conducted by considering the threshold impact beyond which the relationship is no longer linear.

\section{REFERENCES}

Abedifar, P., Hasan, I., \& Tarazi, A. (2016). Finance-growth nexus and dual-banking systems: Relative importance of Islamic banks. Journal of Economic Behavior $\mathcal{F}$ Organization, 132, 198-215. doi: https://doi.org/10.1016/j.jebo.2016.03.005

Abduh. M., \& Omar. M., (2012). Islamic banking and economic growth: The Indonesian experience. International Journal of Islamic and Middle Eastern Finance and Management, 5(1), 35-47. doi: https://doi.org/10.1108/17538391211216811

Abduh. M., \& Chowdhury, N., (2012). Does Islamic banking matter for economic growth in Bangladesh? Journal of Islamic Economics, Banking and Finance, 8(3), 104-113.

Abu-Bader, S., \& Abu-Qarn, A. S. (2008). Financial development and economic growth: The Egyptian experience. Journal of Policy Modeling, 30(5), 887-898. doi: https://doi.org/10.1016/j.jpolmod.2007.02.001

Adamopoulos, A. (2010). Financial development and economic growth an empirical analysis for Ireland. International Journal of Economic Sciences and Applied Research, 3(1), 75-88.

Adnan Hye, Q. M. (2011). Financial development index and economic growth: Empirical evidence from India. The Journal of Risk Finance, 12, 98-111.

doi: https://doi.org/10.1108/15265941111112820

Adnan Hye, Q. M., \& Islam, F. (2013). Does financial development hamper economic growth: empirical evidence from Bangladesh. Journal of Business Economics and Management, 14(3), 558-582. doi: https://doi.org/10.3846/16111699.2012.654813

Adu, G., Marbuah, G., \& Mensah, J. T. (2013). Financial development and economic growth in Ghana: Does the measure of financial development matter?. Review of Development Finance, 3(4), 192-203. doi: https://doi.org/10.1016/j.rdf.2013.11.001

Agbetsiafa, D. (2004). The finance growth nexus: Evidence from Sub-Saharan Africa. Savings and Development, 38, 271-288.

Ahmed, S. M., \& Ansari, M. I. (1998). Financial sector development and economic growth: The South-Asian experience. Journal of Asian Economics, 9(3), 503-517. doi: https://doi.org/10.1016/S1049-0078(99)80100-6 
Arellano, M., \& Bover, O. (1995). Another look at the instrumental variable estimation of error-components models. Journal of Econometrics, 68(1), 29-51. doi: https://doi.org/10.1016/0304-4076(94)01642-D

Arellano, M., \& Bond, S., (1991). Some tests of specification for panel data: Monte Carlo evidence and an application to employment equations. The Review of Economic Studies, 58(2), 277-297. doi: https://doi.org/10.2307/2297968

Atindehou, R. B., Gueyie, J. P., \& Amenounve, E. K. (2005). Financial intermediation and economic growth: Evidence from Western Africa. Applied Financial Economics, 15(11), 777-790. doi: https://doi.org/10.1080/09603100500108030

Bader, M., \& Malawi, A. I. (2010). The impact of interest rate on investment in Jordan: A cointegration analysis. Economics and Administration, 24(1), 199-209.

doi: https://doi.org/10.4197/Eco.24-1.6

Bagehot, W. (1873). Lombard street: A description of the money market. John Wiley \& Sons, Inc.

Batra, R. (1992). The fallacy of free trade. Review of International Economics, 1(1), 19-31. doi: https://doi.org/10.1111/j.1467-9396.1992.tb00004.x

Batra, R., \& Slottje, D. J. (1993). Trade policy and poverty in the United States: Theory and evidence, 1947-1990. Review of International Economics, 1(3), 189-208. doi: https://doi.org/10.1111/j.1467-9396.1993.tb00016.x

Beck, T., \& Levine, R. (2004). Stock markets, banks, and growth: Panel evidence. Journal of Banking $\mathcal{F}$ Finance, 28(3), 423-442. doi: https://doi.org/10.1016/S0378-4266(02)00408-9

Benhabib, J., \& Spiegel, M. M. (2000). The role of financial development in growth and investment. Journal of Economic Growth, 5(4), 341-360.

doi: https://doi.org/10.1023/A:1026599402490

Bittencourt, M. (2012). Financial development and economic growth in Latin America: Is Schumpeter right?. Journal of Policy Modeling, 34(3), 341-355.

doi: https://doi.org/10.1016/j.jpolmod.2012.01.012

Blundell, R., \& Bond, S. (1998). Initial conditions and moment restrictions in dynamic panel data models. Journal of Econometrics, 87(1), 115-143.

doi: https://doi.org/10.1016/S0304-4076(98)00009-8

Bond, S. R., Hoeffler, A. and Temple, J. (2001). GMM estimation of empirical growth models ( Discussion Paper No. 2048). Centre for Economic Policy Research, Nuffield College, Oxford.

Boukhatem, J., \& Moussa, F. B. (2018). The effect of Islamic banks on GDP growth: Some evidence from selected MENA countries. Borsa Istanbul Review, 18(3), 231-247. doi: https://doi.org/10.1016/j.bir.2017.11.004

Campos, N. F., Karanasos, M. G., \& Tan, B. (2012). Two to tangle: Financial development, political instability and economic growth in Argentina. Journal of Banking $\mathcal{E}$ Finance, 36(1), 290-304. doi: https://doi.org/10.1016/j.jbankfin.2011.07.011

Chandavarkar, A. (1992). Of finance and development: neglected and unsettled questions. World Development, 20(1), 133-142. doi: https://doi.org/10.1016/0305-750X(92)90142-I 
Christopoulos, D. K., \& Tsionas, E. G. (2004). Financial development and economic growth: evidence from panel unit root and cointegration tests. Journal of Development Economics, 73(1), 55-74. doi: https://doi.org/10.1016/j.jdeveco.2003.03.002

Creane, A., Goyal, R., Mobarak, A.M., \& Sab, R. (2004). Financial development in the Middle East and North Africa (Working Paper No: WP/04/201). International Monetary Fund, Washington, DC. doi: https://doi.org/10.5089/9781451874389.001

Demetriades, P. O., \& Hussein, K. A. (1996). Does financial development cause economic growth? Time-series evidence from 16 countries. Journal of Development Economics, 51(2), 387-411.

doi: https://doi.org/10.1016/S0304-3878(96)00421-X

Durusu-Ciftci, D., Ispir, M. S., \& Yetkiner, H. (2017). Financial development and economic growth: Some theory and more evidence. Journal of Policy Modeling, 39(2), 290-306. doi: https://doi.org/10.1016/j.jpolmod.2016.08.001

Dutta, N., \& Roy, S. (2009). The impact of financial development on domestic investment: A quantile regression approach. Indian Macroeconomics Annual, 6, 107-130.

Farahani, Y. G., \& Dastan, M. (2013). Analysis of Islamic banks' financing and economic growth: a panel cointegration approach. International Journal of Islamic and Middle Eastern Finance and Management, 3(2), 156-172. doi: https://doi.org/10.1108/17538391311329842

Federici, D., \& Caprioli, F. (2009). Financial development and growth: An empirical analysis. Economic Modelling, 26(2), 285-294.

doi: https://doi.org/10.1016/j.econmod.2008.07.006

Fielding, D. (1997). Adjustment, trade policy and investment slumps: Evidence from Africa. Journal of Development Economics, 52(1), 121-137. doi: https://doi.org/10.1016/S0304-3878(96)00437-3

Fischer, B. (1981). Interest rate ceilings, inflation and economic growth in developing countries. Economics, 23, 75-93.

Fowowe, B. (2011). Financial sector reforms and private investment in Sub-Saharan African countries. Journal of Economic Development, 36(3), 79-97.

doi: https://doi.org/10.35866/caujed.2011.36.3.004

Furqani. H., \& Mulyany. R., (2012). Islamic banking and economic growth: Empirical evidence from Malayisa. Journal of Economic Cooperation and Development, 30(2), 59-74.

Gheeraert, L. (2014). Does Islamic finance spur banking sector development. Journal of Economic Behavior and Organization, 103, S4-S20.

doi: https://doi.org/10.1016/j.jebo.2014.02.013

Gheeraert, L., \& Weill, L. (2015). Does Islamic banking development favor macroeconomic efficiency? Evidence on the Islamic finance-growth nexus. Economic Modelling, 47, 32-39. doi: https://doi.org/10.1016/j.econmod.2015.02.012

Goldsmith, R. W. (1955). Financial structure and economic growth in advanced countries: An experiment in comparative financial morphology. In Capital formation and economic growth (pp. 112-167). Princeton University Press. 
Greene, J., \& Villanueva, D. (1991). Private investment in developing countries: An empirical analysis. Staff Papers, 38(1), 33-58. doi: https://doi.org/10.2307/3867034

Grossman, G. M., \& Helpman, E. (1991). Quality ladders in the theory of growth. The Review of Economic Studies, 58(1), 43-61. doi: https://doi.org/10.2307/2298044

Hansen, L. P. (1982). Large sample properties of generalized method of moments estimators. Econometrica: Journal of the Econometric Society, 50(4), 1029-1054.

doi: https://doi.org/10.2307/1912775

Hasan, I., Wachtel, P., \& Zhou, M. (2009). Institutional development, financial deepening and economic growth: Evidence from China. Journal of Banking $\mathcal{E}$ Finance, 33(1), 157-170. doi: https://doi.org/10.1016/j.jbankfin.2007.11.016

Herwartz, H., \& Walle, Y. M. (2014). Determinants of the link between financial and economic development: Evidence from a functional coefficient model. Economic Modelling, 37, 417-427. doi: https://doi.org/10.1016/j.econmod.2013.11.029

Imam, P., \& Kpodar, K. (2013). Islamic banking: How has it expanded?. Emerging Markets Finance and Trade, 49(6), 112-137. doi: https://doi.org/10.2753/REE1540-496X490607 Imam. P., \& Kpodar, K., (2016). Islamic banking: Good for growth?. Economic Modelling, 59, 387-401. doi: https://doi.org/10.1016/j.econmod.2016.08.004

Inoubli, C., \& Khallouli, W. (2011). Does financial development impact on growth? Empirical evidence with threshold effect in the MENA Region. Paper presented at the 17th Annual Conference: Politics and Economic Development, Antalya, Turkey.

Jalil, A., \& Ma, Y. (2008). Financial development and economic growth: Time series evidence from Pakistan and China. Journal of Economic Cooperation, 29(2), 29-68.

Jorgenson, D. W. (1971). Econometric studies of investment behavior: A survey. Journal of Economic Literature, 9(4), 1111-1147.

Jung, W. S. (1986). Financial development and economic growth: International evidence. Economic Development and Cultural Change, 34(2), 333-346.

doi: https://doi.org/10.1086/451531

Kalim, R., Mushtaq, A., \& Arshed, N. (2016). Islamic banking and economic growth: Case of Pakistan. Islamic Banking and Finance Review, 3(1), 14-28.

Karich, I. (2002). The Islamic financial system: From religion to the bank (Vol. 2). Larcier. Kassim, S. (2016). Islamic finance and economic growth: The Malaysian experience. Global Finance Journal, 30, 66-76. doi: https://doi.org/10.1016/j.gfj.2015.11.007

King, R. G., \& Levine, R. (1993). Finance and growth: Schumpeter might be right. The Quarterly Journal of Economics, 108(3), 717-737. doi: https://doi.org/10.2307/2118406

Kuznets, S. (1955). Economic growth and income inequality. The American Economic Review, 45(1), 1-28.

Leon, F., \& Weill, L. (2018). Islamic banking development and access to credit. PacificBasin Finance Journal, 52, 54-69. doi: https://doi.org/10.1016/j.pacfin.2017.04.010

Levine, R. (2005). Finance and growth: Theory and evidence. In P. Aghion., \& S. Durlauf (Eds.), Handbook of economic growth (Vol. 1). Elsevier.

Levine, R., \& Zervos, S. (1998). Stock markets, banks, and economic growth. American Economic Review, 88, 537-558. doi: https://doi.org/10.1596/1813-9450-1690 
Levine, R., Loayza, N., \& Beck, T. (2000). Financial intermediation and growth: Causality and causes. Journal of monetary Economics, 46(1), 31-77.

doi: https://doi.org/10.1016/S0304-3932(00)00017-9

Levine, R., \& Renelt, D. (1992). A sensitivity analysis of cross-country growth regressions. The American Economic Review, 82, 942-963.

Lewis Jr., R. E. (1955). The theory of economic growth. The Review of Black Political Economy' 34(3), 187-216.

Liang, Q., \& Jian-Zhou, T. (2006). Financial development and economic growth: Evidence from China. China Economic Review, 17(4), 395-411.

doi: https://doi.org/10.1016/j.chieco.2005.09.003

Lucas Jr, R. E. (1988). On the mechanics of economic development. Journal of Monetary Economics, 22(1), 3-42. doi: https://doi.org/10.1016/0304-3932(88)90168-7

Luintel, K. B., \& Khan, M. (1999). A quantitative reassessment of the finance-growth nexus: Evidence from a multivariate VAR. Journal of Development Economics, 60(2), 381-405. doi: https://doi.org/10.1016/S0304-3878(99)00045-0

Mahmood. A. (2014). Impact of financial development on economic growth of Pakistan. Abasyn Journal of Social Sciences, 6(2), 106-116.

Manap, T. A. A., Abduh, M., \& Omar, M. A. (2012). Islamic banking-growth nexus: Evidence from Toda-Yamamoto and bootstrap Granger causality test. Journal of Islamic Finance, 1(1), 59-66.

Matsheka, T. C. (1998). Interest rates, and the saving-investment process in Botswana. African Review of Money Finance and Banking, 1(2), 5-23.

McKinnon, R. I. (1973). Money and capital in economic development. The Brookings Institutions, Washington, DC, WA.

Mehrara, M., Sargolzaei, M., Ahmadi, R., \& Ahmadi, M. (2012). Investigating the relation between financial development and economic growth using ARDL approach case study: Iran. Journal of Basic and Applied Scientific Research, 2(6), 5932-5936.

Muhammad, S. D., Lakhan, G. R., Zafar, S., \& Noman, M. (2013). Rate of interest and its impact on investment to the extent of Pakistan. Pakistan Journal of Commerce and Social Sciences (PJCSS), 7(1), 91-99.

Mundell, R. (1965). Growth, stability and inflationary finance. Journal of Political Economy, 73, 97-109. doi: https://doi.org/10.1086/258999

Mushtaq, S., \& Siddiqui, D. A. (2016). Effect of interest rate on economic performance: Evidence from Islamic and non-Islamic economies. Financial Innovation, 2(1), 1-14. doi: https://doi.org/10.1186/s40854-016-0028-7

Muyambiri, B., \& Odhiambo, N., (2017). The impact of financial development on investment in Botswana: An ARDL-bounds testing approach. International Economics, 70 (2), 193-216.

Narayan, P. K., \& Narayan, S. (2013). The short-run relationship between the financial system and economic growth: New evidence from regional panels. International Review of Financial Analysis, 29, 70-78. doi: https://doi.org/10.1016/j.irfa.2013.03.012 
Nasir, S., Khalid, M., \& Mahmood, A. (2004). Saving-investment behaviour in Pakistan: An empirical investigation [with Comments]. The Pakistan Development Review, 43(4), 665-682. doi: https://doi.org/10.30541/v43i4IIpp.665-682

Ndikumana. L. (2000). Financial determinants of domestic investment in Sub-Saharan Africa: Evidence from panel data. World Development, 28(2), 381-400. doi: https://doi.org/10.1016/S0305-750X(99)00129-1

Ndikumana. L. (2005). Financial development, financial structure, and domestic investment: International evidence. Journal of International Money and Finance, 24, 651-673. doi: https://doi.org/10.1016/j.jimonfin.2005.03.006

Odedokun, M. O. (1996). Alternative econometric approaches for analysing the role of the financial sector in economic growth: Time-series evidence from LDCs. Journal of Development Economics, 50(1), 119-146. doi: https://doi.org/10.1016/0304-3878(96)00006-5

Patrick, H. T. (1966). Financial development and economic growth in developing countries. Economic Development and Cultural Change, 14(2), 174-89. doi: https://doi.org/10.1086/450153

Pradhan, R. P., Arvin, M. B., Hall, J. H., \& Bahmani, S. (2014). Causal nexus between economic growth, banking sector development, stock market development, and other macroeconomic variables: The case of ASEAN countries. Review of Financial Economics, 23(4), 155-173. doi: https://doi.org/10.1016/j.rfe.2014.07.002

Pradhan, R. P., Arvin, M. B., Hall, J. H., \& Norman, N. R. (2017). ASEAN economic growth, trade openness and banking-sector depth: The nexus. Economi A, 18(3), 359-379. doi: https://doi.org/10.1016/j.econ.2017.05.002

Quartey, P., \& Prah, F. (2008). Financial development and economic growth in Ghana: Is there a causal link?. African Finance Journal, 10(1), 28-54.

Robinson, J. (1952). The generalization of the general theory in the rate of interest and other essays. Macmillan.

Rousseau, P. L., \& Wachtel, P. (1998). Financial intermediation and economic performance: historical evidence from five industrialized countries. Journal of Money, Credit and Banking, 30(4) 657-678. doi: https://doi.org/10.2307/2601123

Wolde-Rufael, Y. (2009). Re-examining the financial development and economic growth nexus in Kenya. Economic Modelling, 26(6), 1140-1146.

doi: https://doi.org/10.1016/j.econmod.2009.05.002

Salahuddin, M., Islam, R., \& Salim, S. A. (2009). Determinants of investment in Muslim developing countries: An empirical investigation. International Journal of Economics and Management, 3(1), 100-129.

Schumpeter, J., \& Backhaus, U. (2003). The theory of economic development. In Joseph Alois Schumpeter (pp. 61-116). Springer, Boston, MA. doi: https://doi.org/10.1007/0-306-48082-4_3

Shaw, E. S. (1973). Financial deepening in economic development. Oxford University Press. 
Smaoui, H., \& Nechi, S. (2017). Does sukuk market development spur economic growth?. Research in International Business and Finance, 41, 136-147. doi: https://doi.org/10.1016/j.ribaf.2017.04.018

Spears, A. (1992). The role of financial intermediation in economic growth in Sub-Saharan Africa. Canadian Journal of Development Studies, 13(3), 361-380. doi: https://doi.org/10.1080/02255189.1992.9669467

Stern, N. H. (1989). The economics of development: A survey. Economic Journal, 99(397), 597-685. doi: https://doi.org/10.2307/2233764

Tabash, M., \& Dhankar. R., (2014). The flow of Islamic finance and economic growth: An empirical evidence of Middle East. Journal of Finance and Accounting,2(1), 11-19. doi: https://doi.org/10.11648/j.jfa.20140201.12

Tabash, M. I., \& Anagreh, S. (2017). Do Islamic banks contribute to growth of the economy? Evidence from United Arab Emirates (UAE). Banks E Bank Systems, 12(1-1), 113-118. doi: https://doi.org/10.21511/bbs.12(1-1).2017.03

Tobin, J. (1965). Money and economic growth. Econometrica, 33, 671-684. doi: https://doi.org/10.2307/1910352

Ucan. O., \& Ozturk, O. (2011). Financial determinants of investment for Turkey. Journal of Economic and Social Studies, 1(1)83-110. doi: https://doi.org/10.14706/JECOSS11117

Uddin, G. S., Sjo, B., \& Shahbaz, M. (2013). The causal nexus between financial development and economic growth in Kenya. Economic Modelling, 35, 701-707. doi: https://doi.org/10.1016/j.econmod.2013.08.031

Wai, U. T., \& Wong, C. H. (1982). Determinants of private investment in developing countries. The Journal of Development Studies, 19(1), 19-36. doi: https://doi.org/10.1080/00220388208421848

Yusof, R. M., \& Bahlous, M. (2013). Islamic banking and economic growth in GCC \& East Asia countries: A panel cointegration analysis. Journal of Islamic Accounting and Business Research, 4(2), 151-172. doi: https://doi.org/10.1108/JIABR-07-2012-0044

Zhang, J., Wang, L., \& Wang, S. (2012). Financial development and economic growth: Recent evidence from China. Journal of Comparative Economics, 40(3), 393-412. doi: https://doi.org/10.1016/j.jce.2012.01.001 